\title{
A respeito de uma ânfora do Pintor de Amásis conservada no Cabinet des Médailles da Biblioteca Nacional da França, em Paris: três grandes divindades da Atenas arcaica
}

\author{
Marie-Christine Villanueva Puig ${ }^{[1]}$
}

\begin{abstract}
Resumo
O programa iconográfico de uma ânfora ática de figuras negras, datada de cerca de 540 a. C., assinada pelo oleiro Amasis e atribuído ao Pintor de Amasis (Cabinet des Médailles da Biblioteca Nacional da França, em Paris) é reexaminado. A partir disso, propõe-se avaliar a importância documental das imagens veiculadas pelos vasos numa abordagem de história sócio-religiosa da Atenas arcaica.

Palavras-chave: Atenas arcaica; vida cultual; organização do Cerâmico; artesão.
\end{abstract}

Con respecto de una ánfora del Pintor de Amasis conservada en el Cabinet des Médailles de la Biblioteca Nacional de Francia en Paris: tres grandes divinidades de Atenas Arcaica

\section{Resumen}

El programa iconográfico de una ánfora ática de figuras negras, de más o menos 540 a. C., firmada por el alfarero Amasis y atribuído al Pintor de Amasis (Cabinet des Médailles da Biblioteca Nacional de Francia en Paris) es examinado más una vez. A partir de este hecho, se propone evaluar la importancia de ese documento de las imágenes transmitidas por los jarrones en un enfoque de la história sócio-religiosa de Atenas arcaica.

Palabras-clave: flor; charis; philia.

About an Amasis Painter's amphora kept in the Cabinet des Médailles of France's National Library in Paris: three Archaic Athens'great deities

\section{Abstract}

The iconographic ensemble of an Attic black-figured amphora dated c. 540, signed by Amasis the potter and attributed to the Amasis Painter (Cabinet des Médailles de la Bibliothèque Nationale de France in Paris) is re-examined. The goal of this paper is to give the opportunity of evaluating the importance of the iconographic programme used in the production of vases as a way of understanding the archaic City's social and religious life.

Keywords: Archaic Athens; cultual life; Athenian Kerameikos; craftman.

A propos d'une amphore du Peintre d'Amasis conservée au Cabinet des Médailles de la Bibliothèque Nationale de Francè à Paris : trois grandes divinités de l'Athènes archaïque

\section{Résumé}

Le programme iconographique d'une amphore attique à figures noires, datée vers 540, signée du potier Amasis et attribuée au Peintre d'Amasis (Cabinet des Médailles de la Bibliothèque Nationale de France à Paris), est réexaminé. A partir de celui-ci, on se propose d'évaluer l'importance documentaire des images portées par les vases dans lapproche de l'histoire socio-religieuse de l'Athènes archaïque. Mots-clés: Athènes archaïque; vie cultuelle; organisation du Céramique; artisan. 
ma exposição, Du Rouge et du Noir. Les vases grecs de la collection de Luynes, ${ }^{2}$ reúne, no Cabinet des Médailles da Biblioteca Nacional da França (2014-2015), a prestigiosa coleção de vasos gregos acumulada pelo Duque de Luynes, que a doou à instituição em 1862, com um vastíssimo conjunto de antiguidades variadas: bronzes, moedas, vasos, joias, camafeus etc. Essas obras continuam sendo conservadas pela instituição. O evento oferece uma oportunidade de reexaminar uma das peças, por muitos motivos, excepcional, dessa riquíssima doação. Trata-se de uma ânfora ática com pescoço de figuras negras ${ }^{3}$ (figura $1 \mathrm{AB}$ ), cuja data de fabricação se situa no terceiro quartel do século VI antes da nossa era, por volta de 540. Ela procede das escavações da necrópole etrusca de Vulci e fez parte da coleção Durand antes de pertencer ao Duque de Luynes.

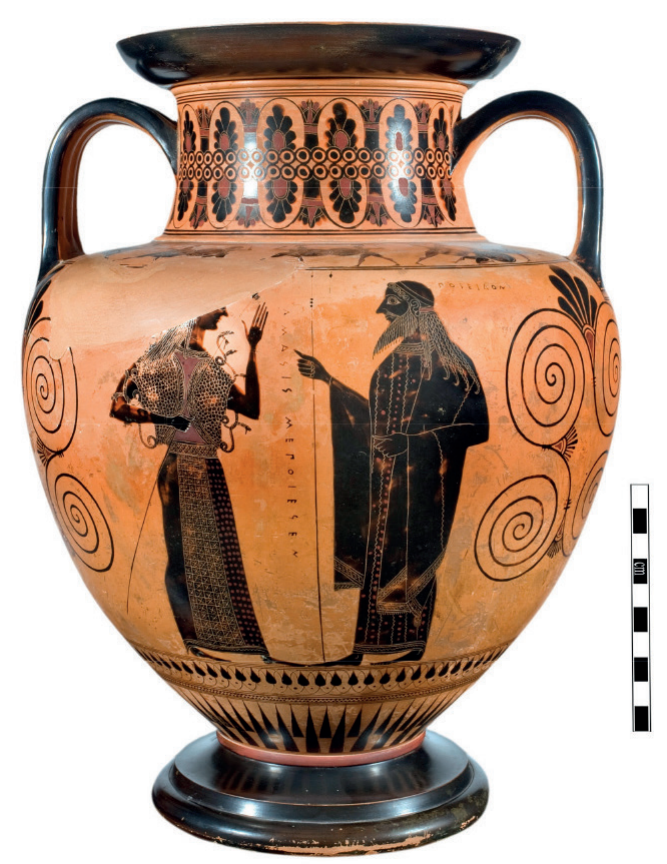

Figura 1A: Ânfora ática com pescoço de figuras negras. 


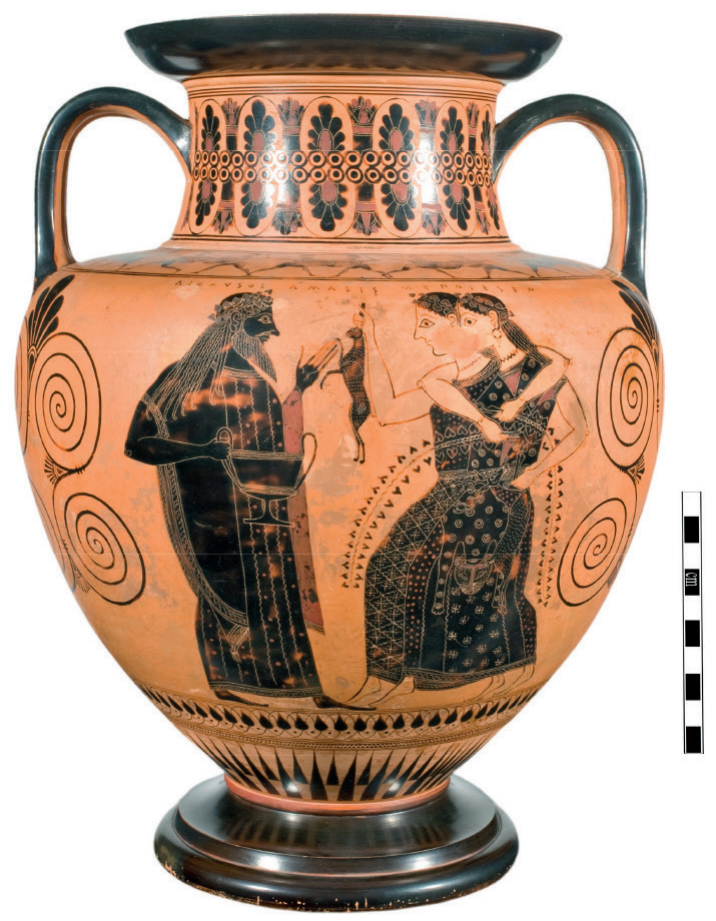

Figura 1B: Ânfora ática com pescoço de figuras negras.

Sua forma elaborada, as qualidades gráficas de sua decoração figurada, seu rico sistema ornamental e seu excepcional programa iconográfico, as inscrições, enfim, que carrega - dentre as quais, uma assinatura -, tudo nos convida a reavaliá-la. A partir dessa obra, gostaria de introduzir, novamente, a questão dos dados que as imagens representadas em vasos pintados podem fornecer ao historiador das sociedades antigas. Ela está, naturalmente, vinculada às questões de seu contexto de produção, da escolha de representações operada, em dado momento de sua história, pela pólis e da imagem que esta busca dar de si. Estaria, também, marcada ou orientada pelo próprio pintor? Pelo seu cliente? Segundo os grupos sociais de difícil identificação, na Atenas arcaica? A qualidade excepcional, unida à profunda originalidade dessa obra, atribuída ao Pintor de Amásis, nos convida a examinar esse ponto.

A forma peculiar da ânfora, bastante atarracada, com alças trífidas, unida a uma rica decoração secundária, fez com que fosse comparada à Botkin Class, ${ }^{4}$ uma pequena série de vasos definida por Beazley ${ }^{5}$ e tradicionalmente considerada como fortemente marcada por uma influência oriental. ${ }^{6}$ Por sua vez, H.

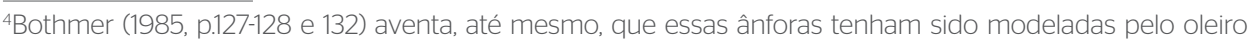
Amásis, no início de sua carreira; ver, a esse respeito, os esclarecimentos de Mommsen (1994), Oakley, Coulson e Palagia (1997, p.17-34).

${ }^{5}$ Beazley (1931, p.284): trata-se de um pequeno grupo (que contém, agora, nove peças), que deve seu nome ao vaso epônimo do Hermitage, em São Petersburgo, B. 4464 (ABV p.159-160,4), tendo este pertencido ao pintor Michail Pavlovitch Botkin.

6Ver, em particular, Jackson (1976, p.29-37 e, em especial, p.34-35 e fig. 17), no tocante ao nosso vaso; Mommsen (1994), Oakley, Coulson e Palagia (1997, p.17-34). 
Mommsen, em estudo recente, (Mommsen 2009, p.31-46) retoma esse ponto para, ao contrário, integrar essa série à produção ática da época, da qual se teria inspirado o oleiro Amásis, em especial, para a nossa ânfora. Sobre essa decoração, cabe notar, em particular, o friso duplo de folhas de palmeiras e botões de lótus no pescoço, o complexo padrão com amplas espirais e palmeiras, com um grande botão de lótus suspenso abaixo das alças, cuja fixação está marcada por triângulos suspensos, e, enfim, a parte inferior da pança, decorada com bordas irradiantes, encimadas por um friso de botões de lótus. Um ar de exotismo a ser acompanhado nos demais aspectos do vaso, embora questionado.

$\mathrm{O}$ vaso apresenta três cenas figuradas: uma de cada lado do pança e uma sobre a espádua. Em cada face do vaso, podem-se ler inscrições: uma assinatura AMASIS MEPOIESEN, "Amásis me fez", a assinatura do oleiro, que aparece duas vezes. Na face $A$, lê-se verticalmente, traçada entre as duas figuras representadas frente a frente. Na face $\mathrm{B}$, ela reaparece, horizontalmente desta vez, localizada acima das cabeças das três figuras. Ademais, estão gravados os nomes dos personagens representados: na face $\mathrm{A}$, acima da cabeça do personagem barbado, à direita, pode-se ler POSEIDON; na face $\mathrm{B}$, em cima do personagem masculino, DIONYSOS.

O ombro do vaso é decorado por um friso miniaturista, muito animado: vê-se nele uma série de duelos de hoplitas, entre os quais se intercala um grupo de três guerreiros, estando um ferido pelo seu adversário e já caído ao chão, enquanto um terceiro combatente se aproxima para ajudá-lo. Todos vestem o mesmo equipamento: elmo de tipo coríntio e cimeira alta, couraça, cnêmides, escudo redondo e lança. Por baixo das alças, um homem soa o alarme, soprando um corno, e um arqueiro, com touca oriental pontuda, foge, virando-se para trás.

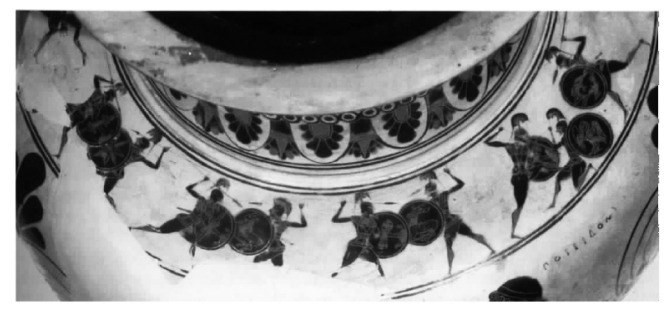

Figura 2A:

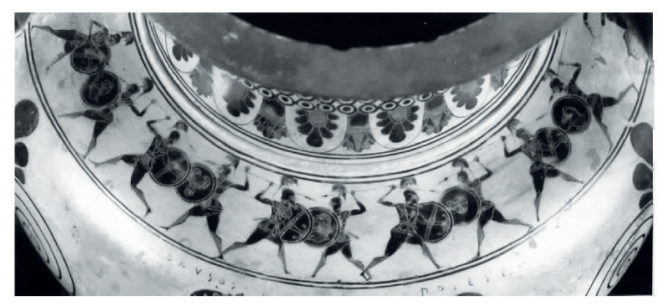

Figura 2B:

As duas cenas que decoram a pança da ânfora contrastam com a violenta agitação da cena de combate do ombro. Na face A, estão representadas, em 
pé, imóveis e frente a frente, uma figura feminina e uma masculina, separadas pela assinatura vertical de Amásis, já apontada. À esquerda, encontrava-se, sem dúvida, outra inscrição, hoje desaparecida, como a que ainda pode ser lida perto do personagem da direita. A deusa Athená, porém, é facilmente reconhecível. Ela veste um péplos ricamente bordado. Sobre os ombros, ela carrega a égide, encontrando-se a pele de cabra figurada por escamas e bordeada de serpentes, que se destacam com clareza sobre a argila do vaso. Trata-se de um presente de Zeus, seu pai, que a torna invulnerável. Ela portava um elmo sobre seus longos cabelos, do qual somente o protetor de nuca se conservou. Na mão direita, ela segura uma lança. A deusa avança em direção do personagem que a defronta, levantando a mão esquerda, em um gesto de saudação. À sua frente, está Poseidon, identificado por uma inscrição, como vimos, e igualmente reconhecível graças ao tridente que empunha na mão esquerda e o designa como soberano dos mares. Está vestido com um longo chiton plissado e um himation. Seus cabelos trançados estão presos com uma faixa.

Na face B da pança, à esquerda, encontra-se Dionysos, cujo nome está gravado acima da cabeça. É representado como um deus de idade madura, como era costume na época arcaica: ele é barbado e tem cabelos longos, como Poseidon, na outra face. No entanto, seus cabelos não estão trançados, e sim, coroados de hera. Ele segura, com a mão direita, um grande cântaro, um vaso para beber, com alças altas. A hera, de folhagem sempre verde, e o vaso de vinho são, de fato, dois de seus atributos característicos e habituais. Sua mão esquerda está levantada na direção de duas mênades, ${ }^{7}$ que avançam em sua direção com passo vivo e dançante. Além disso, cada uma passa o braço por cima do ombro da outra. Ambas estão coroadas de hera, como o deus, e cada uma delas segura um ramo de hera na mão. Estão vestidas com um péplos ricamente bordado e cinturado, além de usarem joias: brincos, colares e pulseiras. A mais afastada do espectador entrega a Dionysos uma lebre, que ela segura pelas orelhas. A mais próxima veste uma pele de pantera (pardalide), amarrada em cima de seu péplos: distinguem-se a cabeça e as patas do animal. Na mão esquerda, ela segura um filhote de enho. Nota-se, assim, nessa figura, três motivos diferentes, superpostos: o bordado do péplos, a pele ocelada da pantera e a do enho, sarapintada - um resultado virtuose no uso da incisão, característica da técnica das figuras negras. As mênades estão representadas como caçadoras que trazem os produtos de sua caça, em homenagem ao seu deus.

Várias fontes escritas permitem traçar um quadro histórico em que Athená, Poseidon e Dionysos, representados na ânfora, são três grandes divindades da Atenas arcaica. O vaso foi criado durante o período em que o tirano Pisístrato governou a pólis (ele toma o poder pela primeira vez em 560 e, em seguida, governa Atenas ininterruptamente de 546-545 até sua morte, em 528-527, quando seus filhos o sucedem, até 511-510). Porém, a ele é atribuído um papel

${ }^{7} \mathrm{~A}$ designação dessas figuras femininas em volta de Dionysos é bastante controversa. Expliquei sobre a minha escolha de chamá-las de "mênades" (2009, p.22-23). Ver a respeito das ocorrências literárias desses termos, Bonansea (2008, p.107-130) e um bom balanço da questão Lindblom (2011, p.135-146); outro ponto de vista em Isler-Kerényi (2015, p. 4-8). 
importante na orientação do desenvolvimento religioso, ${ }^{8}$ incluindo uma importante transformação da grande festa Panateneias, que celebra Athená, a divindade políade, com notável desenvolvimento do programa de manifestações. O tirano apresentava a si mesmo como o escolhido pela deusa para governar a sua pólis: é o que nos revela a história da estranha encenação de um de seus retornos a Atenas, relatada por Heródoto, segundo a qual ele subiu de carruagem à Acrópole, acompanhado por uma mulher grande e bela, que ele apresentou como a própria Athená. ${ }^{9}$ Quanto a Poseidon, sua importância na história de Atenas é mais difícil de identificar com precisão. De fato, no mito de fundação da pólis, na época em que os deuses competiam para reinar sobre as diferentes cidades gregas, como divindades políades, e dividir as suas homenagens, Poseidon foi derrotado por Athená, e a cidade, nomeada Atenas. ${ }^{10}$ No período clássico, fontes literárias e figuradas, em especial, o frontão oeste do Partenon, concebido por Fídias, comprovam esse conflito, ao qual retornarei mais adiante. Mas o que sabemos da posição de Poseidon na Atenas arcaica? Pisístrato teria tido, por esse deus, um especial apego, relacionado ao laço de parentesco que reivindicava em relação ao herói homérico Neleu de Pilos, filho de Poseidon. Neleu era pai de Nestor, cujo filho, que se chamava, justamente, Pisístrato, recebeu Telêmaco, à procura de notícias sobre o seu pai, Ulisses, no canto III da Odisseia. ${ }^{11}$ Ora, na Atenas do século VI a. C., os poemas homéricos eram bastante conhecidos, e é difícil imaginar o nome de Pisístrato sem referência a Homero. ${ }^{12}$ Pisístrato favoreceu, sem dúvida, de uma forma ou outra, $o$ culto ao deus patrono de seus heroicos antecepassados. ${ }^{13} \mathrm{O}$ culto a Dionysos teve, por fim, na Atenas dos Pisistrátidas, um especial desenvolvimento, que propomos atribuir a uma escolha deliberada do tirano. ${ }^{14}$ Ele teria introduzido o culto a Dionysos Eleuthereus e instituído as Grandes Dionisíacas, que receberam, a partir de 536, concursos trágicos. ${ }^{15}$ Seria em sua qualidade de divindade reguladora, emblemática da unidade e da pacificação buscadas pelo tirano, que o culto a Dionysos teria sido favorecido por ele. ${ }^{16}$ No tocante aos vasos pintados, o imaginário dionisíaco é extremamente presente, cabendo lembrar, ainda, para avaliar esse dado com a maior precisão possível, que muitos vasos serviam, de modo geral, ao consumo de vinho, no contexto do symposion, uma

\footnotetext{
${ }^{8}$ A obra de Shapiro (1989, e seu suplemento, de 1995) constitui uma pesquisa especialmente rica e documentada sobre esse tema; ver, também, Simonetta (1997).

${ }^{9}$ Heródoto $1,60$.

${ }^{10}$ Ver o relato desse episódio em Apolodoro (Biblioteca III, 14); a respeito desse confronto nos primórdios da pólis de Atenas, ver, em particular, a análise de Loraux (1981, p.204-205). Parker (1987, p.187-214).

"Odisseia, III, 36.

${ }^{12}$ Heródoto V, 65, menciona a relação entre o nome do tirano e o do filho de Nestor.

${ }^{13}$ Ver Shapiro (1989, p. 103-104)

${ }^{14}$ Shapiro (1989, p.85-87) e Isler-Kérényi (2007, p.218-223), para visões matizadas das relações entre o tirano e o culto dionisíaco e para um balanço de sua estratégia, nesse âmbito.

${ }^{15}$ Parker (1996, p.92 e ss.) é, no entanto, cético sobre a atribuição dessas inovações durante a tirania dos Pisistrátidas.

${ }^{16}$ Angiolillo (1997, p.142) e Isler-Kérényi (2015, p.220); Stähli (1999, p. 195-196) destaca a mudança de função do deus na Atenas da época. A reorganização de suas festas corresponde a uma maior integração de seu culto na pólis: Dionysos torna-se um deus urbano.
} 
das áreas nas quais o deus é mestre. ${ }^{17}$ Notou-se, também - desta vez, como característica desse momento específico -, a forte presença de elementos cultuais nesse imaginário, sendo, sem dúvida, interessante relacioná-la a inovações nesse âmbito. ${ }^{18}$

Fontes de outro tipo permitem corroborar a importância das três divindades representadas na ânfora, na Atenas da época. Uma vez estabelecido esse quadro histórico geral relativo à criação da imagem, graças a documentos de outra espécie, avançar implica introduzir o vaso em uma dupla série de representações: a imagem das divindades para o nosso pintor é igual ou diferente de suas figurações por outros pintores? Se for o caso, é o próprio corpus do pintor, então, que deve ser questionado, ressituando-se as cenas do nosso vaso para captar, da melhor forma possível, a sua originalidade e sua margem de liberdade na escolha e no tratamento de seus temas.

\section{O tirano apresentava a si mesmo como o escolhido pela deusa para governar a sua pólis}

Examinemos mais de perto o programa iconográfico da ânfora de Paris, na ótica de localizar os traços pertencentes às tradições e aqueles que, pelo contrário, representam uma novidade. Na face A do vaso, o encontro entre Athená e Poseidon é pacífico, sendo que a tradição mais comum se refere ao combate pela posse da Ática. A fonte escrita mais antiga sobre esse conflito é Heródoto, que compôs as Histórias cerca de um século após nosso vaso. ${ }^{19}$ Plutarco, que escreveu durante o século I da nossa era, evoca, na Vida de Temístocles, esse combate e a vitória de Athená, ao relatar o desenvolvimento do porto de Pireu por Temístocles. Ele queria vincular e, de alguma forma, associar a pólis ao mar, conduzindo, assim, uma política contrária à dos antigos reis de Atenas, que buscavam desviar os cidadãos do mar e vê-los cultivar a terra. Segundo Plutarco, foi nesse intuito que eles teriam difundido a história da rivalidade entre as duas divindades e a vitória da oliveira de Athená contra o mar de Poseidon. A representação mais famosa desse embate é aquela concebida por Fídias para o frontão oeste do Partenon, executada nos anos 438-432. Sua localização na Acrópole, local onde o episódio ocorreu, e sua posição no próprio edifício, em consonância com a cena do nascimento da deusa - que ocupa, ao leste, o frontão principal -, realçam o valor da imagem, em sua qualidade de episódio ligado aos próprios fundamentos da pólis e do nome que carrega. Sobrou pouquíssimo dessa obra, mas um desenho, realizado em 1674, antes da explosão

${ }^{17}$ Sobre esse ponto, ver, em especial, Shapiro (p.84 e 100).

${ }_{18}$ Ver a sutil análise de Stähli (1999, p.195-196) sobre a função da imagem menádica e suas relações com o universo cultual: a afirmação dessa iconografia nos vasos corresponde a uma maior demanda da clientela da época, assim como à sua diversificação, sem que possamos identificar, na implementação ou na modificação dos cultos, a origem, propriamente dita, do tipo iconográfico da mênade; ver, também, Isler-Kerényi (2015, p.221-222).

19Heródoto, História, VIII, 155. 
que danificou o edifício em 1687, permite restituir sua composição geral. ${ }^{20}$ Ao centro do frontão, as duas divindades se enfrentam em um movimento de luta violento e divergente, indicado por uma composição em $\mathrm{V}$ na qual os corpos dos dois adversários estão retesos e projetados para trás. O grupo central está rodeado pelos cavalos das quadrigas dos dois oponentes, que se encabritam. Nos ângulos, encontram-se, provavelmente, Kékrops, rei originário, metade homem, metade serpente - já humanizado, mas ligado, ainda, às monstruosas criaturas saídas da terra -, e sua filha Pandrosos, com uma serpente ajudando a identificar sua presença. ${ }^{21} \mathrm{~A}$ fama da obra ecoa em composições de pintores de vasos de épocas posteriores. Por exemplo, uma hydria ática de figuras vermelhas, datada de 400 a. C., aproximadamente, e proveniente de Pella, ${ }^{22}$ parece inspirar-se da vigorosa composição timpânica: ao centro, o grande raio de Zeus separa os adversários. À esquerda, Athená encontra-se parcialmente conservada. Aos seus pés, percebe-se a oliveira, uma Niké, sinal de sua vitória no conflito, e Kékrops, metade homem, metade serpente, que fixa a cena em Atenas, tanto nas terras da pólis quanto em seu passado distante. À direita, representa-se Poseidon como um hoplita. Ele está recuando com vivacidade e, atrás dele, Anfitrite, sua esposa, segura o seu cavalo, branco e encabritado. Aos seus pés, encontram-se representados um golfinho e um monstro marinho.

\section{Na face A do vaso, o encontro entre Athená e Poseidon é pacífico, sendo que a tradição mais comum se refere ao combate pela posse da Ática}

Contudo, Poseidon, o perdedor, continua efetivamente presente em Atenas e, até mesmo, na Acrópole, onde as marcas de sua ocupação remontam ao mais distante passado de Atenas. De fato, ele é um dos deuses e heróis cultuados no Erecteion, complexo edifício construído ao Norte da Acrópole, no final do século V a. C., onde divide um altar com Erecteu. No segundo século da nossa era, o viajante Pausânias vê nele, ainda, a marca do tridente da divindade sobre

\footnotetext{
${ }^{20}$ Claude Rolley, La sculpture grecque 2 La période classique, Paris, Picard (1999, p.71, fig. 59 e p. 76-78); o desenho, feito pelo Marquês de Nointel, embaixador da França em Constantinopla, é tradicionalmente atribuído a J. Carrey, desenhista oficial do Marquês, mas que, provavelmente, não estava com ele em Atenas; os fragmentos conservados estão dividos entre o British Museum, em Londres, e o Museu do Louvre, em Paris.

${ }^{21}$ Sobre Cécrope, ver, em especial, Laurent Gourmelen. Kékrops, le roi-serpent: imaginaire athénien, représentations de l'humain et de l'animalité en Grèce ancienne, Paris, Les Belles Lettres, Études anciennes, 2004.

${ }^{22}$ Museu de Pella Ma 80.514: BA 17333. Hesperia (82, 2013, p. 597-602, fig. 1-8); ver também, uma hydria com figuras em relevo, proveniente de Kerch, na Crimeia, conservada no Hermitage de São Petersburgo, KAB6A, datada do segundo quarto do século IV (BA 6988; Antike Kunst 54, 2011 pl. 6, 1-2): Poseidon segura o seu cavalo, tendo, aos seus pés, dois golfinhos (referência ao mar salgado) e, em frente dele, Athená, com o galho de oliveira e uma Niké (uma Vitória), perto dela.
} 
a rocha e um poço no qual se escuta o barulho das ondas, vestígios da luta de Poseidon para reivindicar os seus direitos sobre a Ática. ${ }^{23}$

No nosso vaso, do terceiro quartel do VI século a. C., as duas divindades são representadas em uma confrontação pacífica e solene, sem qualquer elemento que evoque a disputa. Trocam um gesto de saudação. Essa representação não é totalmente isolada. Primeiramente, como precursora da cena da ânfora de Paris, cabe citar a surpreendente cena representada em um prato votivo de Tasos, de figuras negras, datado do segundo quartel do século VI a. C. Artefato proveniente do Arthémison de Tasos, constitui uma referência para o Pintor de Poseidon e Athená. A composição reúne três figuras. Ao centro, reconhece-se Poseidon, graças ao seu tridente. À sua frente, encontra-se, muito provavelmente, Athená, embora ela não carregue elmo, égide, lança ou escudo. A identidade do terceiro personagem, à esquerda, é mais problemática. Ele tem altura bastante inferior aos outros dois e veste, por cima de uma túnica curta, uma pele de animal, amarrada. Propôs-se identificar Hermes ou, ainda, Héracles (figura 3). ${ }^{24}$ Haveria, nessa composição, uma referência ao episódio da disputa pelo domínio da Ática - dificilmente justificável, em uma época tão antiga e no contexto de Tasos?

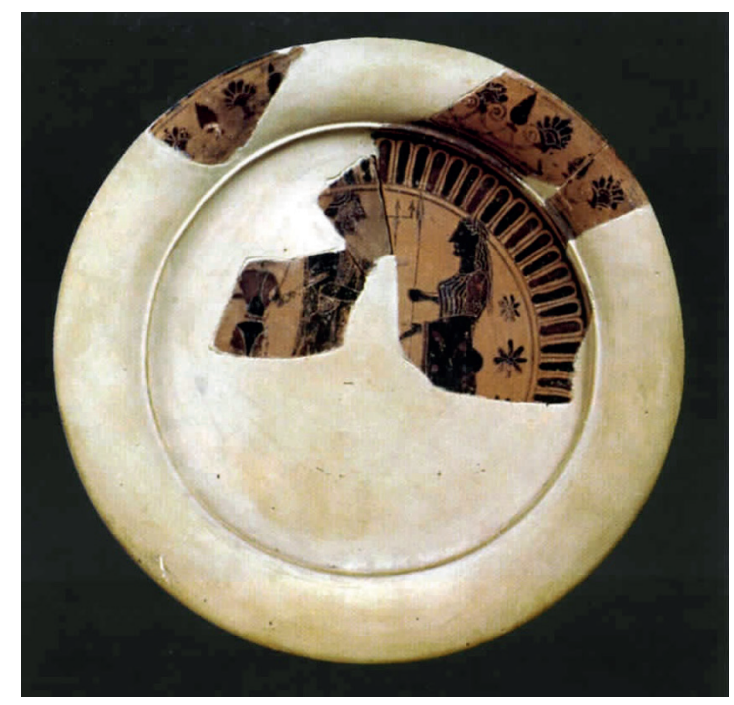

Figura 3: Prato votivo de Tasos.

Observemos, agora, o contexto ateniense e, mais especificamente, o da Acrópole. Nela, encontraram-se dois fragmentos de um cótilo-cratera, atribuídos à Sófilos. ${ }^{25}$ Em um deles, o nome de Poseidon está escrito ao longo de

\footnotetext{
23Pausânias I, 26,5, comentado recentemente por Pirenne-Delforge (2010, p. 147-163); Eurípides escreveu uma tragédia, Erecteu, com alguns fragmentos conservados, que se tentou relacionar à construção do Erecteion, nos últimos vinte anos do século V (Jouan e Van Loy, 2000); sobre Poseidon em Atenas, após a vitória de Athená, ver, também, a nota 33 ${ }^{24}$ Coulié (2002, p.54-55 e pl. II).

${ }^{25}$ Acr. 585 A e B: ABV 40,17 e 18; BA 28625: Bakir (1981, p.68 A17, p.26-27, fig. 17-18, pl.36); Baurain-Rebillard (1999, p.159); Sourvinou-Inwood (2008, p.128-131); Pala (2012, p.112-113 e fig. 52).
} 
uma cabeça de cavalo e, em frente desta, há uma figura masculina barbada, ao lado de uma feminina. Seria possível identificar essas duas figuras como o casal Poseidon e Anfitrite, mas a inscrição pode corresponder, também, a uma figura hoje desaparecida, perto do cavalo. No segundo fragmento, encontram-se duas figuras femininas, que dividem o mesmo manto. Uma delas é designada, por meio de uma inscrição, como Pandrosos, podendo a outra ser uma de suas duas irmãs, preferencialmente, Aglaure ${ }^{26} \mathrm{O}$ homem barbado, à direita delas, seria Kékrops, o pai. Esse vaso, oferecido na Acrópole um pouco antes de 580 a. C., mostraria Poseidon com Pandrosos e, talvez, Kékrops, em uma cena que pertenceria ao mais remoto passado de Atenas. Se admitirmos a interpretação proposta recentemente, ${ }^{27}$ os dois grupos, que misturam divindades e mortais, e a presença de Kékrops - que aparece, às vezes, como um juiz no conflito permitiriam identificar uma cena relacionada ao confronto. Nesse caso, o mito já não corresponderia a uma invenção dos anos 470, remontando, pelo contrário, muito mais longe no tempo. O plano da composição do conjunto nos escapa, mas as partes conservadas restituem as circunstâncias e alguns participantes do combate.

Aliás, outro vaso fragmentado, também proveniente da Acrópole, poderia apresentar uma cena igualmente relacionada ao episódio da competição entre as duas divindades, ali transcorrido. Trata-se de uma ânfora pseudo-panatenaica, datada de 540 a. C., aproximadamente, e atribuída ao Pintor de Princeton (figura 4AB). ${ }^{28}$ À figura de Athená armada, em posição de ataque, entre duas colunas encimadas por um galo, não corresponde, na outra face, uma cena atlética, como reza a tradição, mas sim uma reunião de divindades. Identifica-se Athená, representada entre Poseidon, que está atrás dela, reconhecível pelo seu tridente, e Zeus, na frente dela, que a defronta segurando um raio. Dois estudos ${ }^{29}$ evidenciam os elementos dessa cena que a vinculam ao famoso conflito: os três protagonistas, Athená, Poseidon e Zeus, como árbitro, que toma partido em favor de sua filha, representada à sua frente. Embora toda a análise de uma representação tão fragmentada só possa ensejar extrema prudência, a alusão à rivalidade parece muito provável. Em todo caso, no fragmento conservado, Athená e Poseidon estão um atrás do outro, e o confronto, propriamente dito, não é representado. A cena situa-se antes ou depois do momento crítico. Athená, seguida por Poseidon, está de frente para o seu pai, o rei dos deuses, e sua vitória, iminente ou recentemente conquistada, está assegurada. ${ }^{30}$

\footnotetext{
${ }^{26}$ Como Pandrosos, Aglauro tem espaço no contexto religioso ateniense: Pausânias menciona o seu 'recinto sagrado' (I, 28,2), enquanto a terceira irmã, Herse, mais apagada, é uma espécie de duplicata de Pândroso; para o papel das filhas de Cécrope no voto que dá a vitória a Athená, segundo uma fonte tardia (Élio Aristides), que poderia veicular uma versão antiga, ver Pala (2012, p.115, nota 180).

27Ver as referências citadas na nota 27.

${ }^{28}$ Acr. 923: Marx (2011, p.21-27); Pala (2012, p.115); Moore (2013, p.26-36).

${ }^{29}$ Ver Marx e Moore (supra nota 31).

30 Uma lekanis fragmentada de figuras vermelhas (Acr 594), datada de 400, aproximadamente, é mencionada por Pala (2012, p.111 e fig. 49-50-51) como único outro exemplo seguro da luta, proveniente da Acrópole.
} 


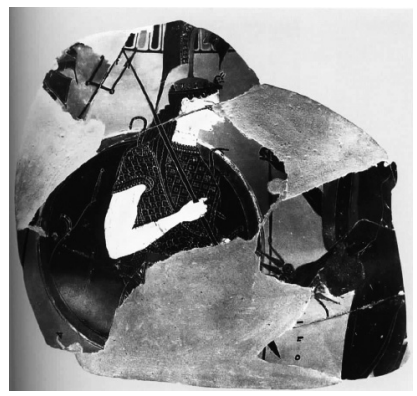

Figura 4A:

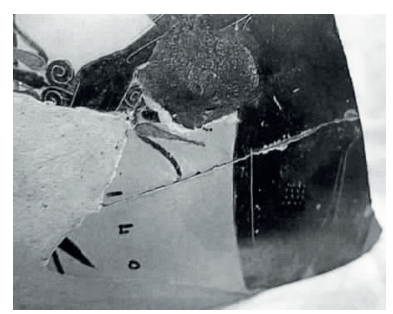

Figura 4B:

Com base nesses dois vasos fragmentados, valeria a pena reconsiderar o prato de Tasos, obra de um artesão aberto à influência de Atenas. ${ }^{31}$ Apesar da presença de um terceiro personagem, pode a imagem, que reúne as duas divindades em uma confrontação pacífica, ser associada à temática da rivalidade que as opôs? Em todo caso, esses dois vasos fragmentados confirmam, muito provavelmente, a antiga existência do épisodio mítico. A novidade na cena do frontão do Partenon, retomada nas imagens dela derivadas, residiria no momento escolhido: o momento no qual tudo se precipita, com uma ousada composição para comunicá-lo.

A composição do Pintor de Amásis contrasta fortemente com aquelas que representam uma ríspida concorrência entre as duas divindades pela supremacia em Atenas e na Ática. Nenhuma violência está subjacente na figuração dessa confrontação divina, ao mesmo tempo pacífica e solene. Deve-se entender que, após a vitória de Athená, que parece pertencer efetivamente ao antigo sedimento dos mitos relacionados à Acrópole, as relações entre as duas divindades se acalmaram e que cada uma delas encontrou seu espaço na colina que domina a pólis ? $^{32}$ Aliás, como imaginar, em uma pólis, e, ainda mais, em Atenas, o apagamento de uma divindade como Poseidon, "movedor da terra", cujos poderes se estendem sobre os mares, mas também sobre todos os movimentos vindos das profundezas da Terra: sismos e catástrofes naturais, e, além disso, vinculado ao cavalo? Em todo caso, em se tratando de pintores áticos da época arcaica, essa representação permanece única. Poseidon e Athená podem

${ }^{31}$ Ver Coulié (2002, p.43-44).

32Sobre Poseidon, o "perdedor", ver, em particular, Parker (1987, p.199); sobre o espaço de Poseidon em Atenas após a vitória da deusa, Darthou (2008, p.269-285). 
participar, juntos, de eventos importantes na vida dos deuses olímpicos, como o milagroso nascimento da deusa, no qual Poseidon, reconhecível pelo seu tridente, está presente, segundo os mais antigos testemunhos conservados, ${ }^{33}$ ou, ainda, na Gigantomaquia, a luta dos deuses contra os gigantes, na qual Athená desempenha um papel proeminente. ${ }^{34}$ Poseidon pode, também, estar presente entre as divindades que recebem Héracles, conduzido por Athená, no Olimpo. ${ }^{35}$ Mas a participação em um mesmo evento não implica uma especial aproximação entre eles, como representado na ânfora de Paris. O único paralelo com essa cena encontra-se em um vaso, ao mesmo tempo muito mais tardio e único, uma ânfora panatenaica em miniatura de figuras vermelhas, datada aproximadamente de 400 a. C., ${ }^{36}$ em que se vê Poseidon em pé, com a perna esquerda levantada e o pé apoiado sobre uma rocha, segurando seu tridente diante de Athená, armada. Na outra face do vaso, Hermes está representado entre duas oliveiras. Dessa forma, a rivalidade é evocada e a confrontação, ao mesmo tempo, apaziguada, ligando-se, aparentemente, os dois tempos.

\section{A composição do Pintor de Amásis contrasta \\ fortemente com aquelas que representam uma ríspida concorrência entre as duas divindades pela supremacia em Atenas e na Ática}

Além disso, ao debruçar-nos sobre o corpus do Pintor de Amásis, pode-se notar uma presença muito importante de Poseidon, que não tem equivalente nos demais pintores de vasos de sua época. Primeiramente, cabe mencionar um encontro muito próximo entre Athená e Poseidon, em outra ânfora assinada pelo oleiro Amásis e atribuída ao Pintor de Amásis. ${ }^{37} \mathrm{~A}$ face $\mathrm{A}$, na qual estão, frente a frente, Athená e Poseidon, não está intacta, mas a identidade das duas figuras incompletas não deixa dúvidas. Encontra-se o mesmo agrupamento em uma oenochoé conservada em Florença, ${ }^{38}$ na qual as duas divindades não aparecem sozinhas, e sim, cercadas por duas outras figuras masculinas, cada uma

\footnotetext{
${ }^{33}$ Por exemplo, no exaleiptron ático de f.n. atribuído ao Pintor C, no Louvre CA 616, aproximadamente 570560: ABV 58,112; BA 300499; Denoyelle (1994, p. 66-67).

${ }^{34}$ Por exemplo, em uma ânfora atribuída ao Pintor do Vaticano 365, Munich SH 1437, aproximadamente 540 : BA 745; CVA 7, pl. 339-340.

${ }^{35}$ Por exemplo, na cratera em forma de cálice de Exéquias, Atenas, Museu da Ágora AP 1044: ABV 145,19; BA 3104 01; Mackay (2010, pl. 81): Poseidon está no cortejo que acompanha Héracles, a caminho do Olimpo; na ânfora de Exéquias em Orvieto, coleção Faina 2748: ABV 144,9; BA 310391; Mackay (pl. 40-41): ele figura entre os deuses olímpicos entre os quais o herói tomou lugar.

${ }^{36}$ Baltimore, Walters Art Gallery 48.59: Godess and polis the panathenaic festival in ancient Athens, cat. exposição sob a direção de Jennifer Neils, The Trustees of Darmouth College, Hanover (New Hampshire) e Princeton University Press, Princeton (New Jersey), p. 45 e p. 189, n66; a representação é associada ao grupo esculpido de Athená, que faz surgir a oliveira, e Poseidon, a onda mencionada por Pausânias, na Acrópole $(\mathrm{I}, 25,3)$.

${ }^{37}$ Boston 01.80.26, em que, aliás, Dionysos também figura, duas vezes, embaixo de cada alça, munido de grandes ramos de videira e hera: ABV 152,26 e 687; BA 310453; Bothmer (1985, p.130-133, n²4).

${ }^{38}$ Florença, Museu arqueológico 379: ABV BA. Esposito e Tommaso (1993, p.32, fig.31).
} 
acompanhada por um cachorro. Uma delas pode facilmente ser reconhecida como Hermes. Uma cena representada em uma olpe conservada no museu do Louvre $^{39}$ é mais complexa. Trata-se do episódio bem conhecido da introdução de Héracles no Olimpo. Hermes e Athená guiam o herói, como de costume. No entanto, não é Zeus, e sim Poseidon que recebe o cortejo. Conhece-se apenas outro exemplo que poderia representar o deus dos mares nessa função. ${ }^{40}$ Deve-se atribuir a essa insólita presença um significado forte, como o propunha Pottier, ${ }^{41}$ que fala da apresentação do herói a Poseidon, como antigo proprietário da Acrópole, pela sua protetora, Athená, e o introdutor habitual das embaixadas divinas, Hermes? A questão continua aberta, mas indica uma situação extraordinária a respeito de Poseidon, confirmada, ainda, por outras obras do nosso pintor, cujos contextos são mais difíceis de elucidar. Em uma olpe fragmentada conservada em Oxford, ${ }^{42}$ o contexto da cena, que reúne cinco figuras, nos escapa. Ao centro, porém, estão frente a frente Poseidon, segurando seu tridente, e Athená, usando o elmo, segurando sua lança e seu escudo, cujo episema consiste em um raio impressionante. Dois elementos característicos do corpus do nosso pintor estão reunidos nessa cena: uma posição especial, dada a Poseidon - em particular, junto a Athená -, e um gosto pelas cenas que reúnem figuras divinas e personagens sem qualquer atributo e de condição indeterminada, talvez simplesmente humanos em uma situação obscura para nós. ${ }^{43}$ As duas faces de uma ânfora conservada em Copenhague ${ }^{44}$ também apresentam esse tipo de reunião: lado a lado, figuras divinas identificáveis e personagens cuja identidade é incerta em um contexto que nos escapa. Nela, encontram-se novamente Poseidon e Athená, mas, dessa vez, cada um em uma face diferente. Acontece o mesmo no reverso de uma ânfora do Museu do Louvre, ${ }^{45}$ que reúne três personagens: à direita, Poseidon é claramente identificável pelo tridente e, à sua frente, o personagem masculino, armado e com elmo, segurando um cachorro preso em uma coleira composta de grandes anéis, continua anônimo para nós (aventou-se que se trataria de Ares). À direita, uma figura feminina poderia ser Athená ou, ainda, Afrodite. O encontro das duas divindades é incerto aqui, mas a presença de Poseidon, comprovada. Por fim, uma taça atribuída ao nosso pintor ${ }^{46}$ representa Poseidon em um episódio homérico, do qual não se conhece outro exemplo de representação. No início do canto 13 da Ilíada, ${ }^{47}$ Poseidon sai de seu palácio de ouro, no fundo dos mares, para encorajar os gregos a retomarem o combate contra os Troianos. Na face A da

\footnotetext{
39Louvre F 30: ABV 152,29 e 687; BA 310456; Bothmer (1985, p.140-142, n² 27).

${ }^{40}$ Ânfora do Pintor de Antímenes, conservada no Museu Nacional de Tarquínia, RC 1871: ABV 270, 64; BA 320074: a cena reúne Héracles, cercado por Hermes e Poseidon.

41Pottier (1889, p.31-37) situa a cena no contexto de "conciliação" entre o culto jônico, personificado por Poseidon e Athená, e o culto dórico, representado por Héracles, sem dúvida ultrapassado; ele aproxima, contudo, a olpe e a ânfora do Cabinet des Médailles, ambas testemunhas das preocupações religiosas da época. ${ }^{42}$ Oxford 1929.19: ABV BA; Bothmer (1985, p.145-146, n² 29).

${ }^{43}$ Aspecto observado por Boardman (1987, p. 147).

${ }^{44}$ Copenhague, Museu Nacional 14347: Paralipomena 65; BA 350466; Bothmer (1985, p. 99-101, n¹3.

${ }^{45}$ Louvre F 25: ABV 150,4 e 687; BA 310431; Bothmer (1985, p.97-98, n 12).

${ }^{46}$ Nova lorque, MMA 1989.281.62 (ex-coleção N. Schimmel, Kings Point (NY) Attribution Herbert Hoffman: Paralipomena 67; BA 350483; Bothmer (1985, p.217-220, n 60)

${ }^{47}$ llíada, 13, 10-58.
} 
taça, estão representadas as estrebarias do soberano dos mares: colunas, que suportam um entablamento de métopas e tríglifos, indicam o local da cena, no qual figuras masculinas de diferentes tamanhos se ocupam em torno dos cavalos. Na face B, o deus do tridente, em pessoa - embora, na narrativa homérica, ele tome, para a ocasião, a aparência do vidente Calcas -, encoraja dois hoplitas, nos quais reconhecemos os dois Ajax.

Essa pesquisa rápida dentro do corpus iconográfico do Pintor de Amásis evidencia a importância do deus Poseidon nas suas escolhas e/ou nas de quem as orienta. Ele está mais presente do que nas outras obras da mesma época. ${ }^{48}$ Nota-se, ainda, uma tendência peculiar em representar o deus diante de Athená, em um tête-à-tête pacífico, quer estejam sozinhos, quer cercados de outras figuras. O deus aparece, também, em contextos em que não seria esperado, como na introdução de Héracles no Olimpo. Por fim, não se conhece nenhum paralelo figurado da cena homérica da qual é protagonista.

Observemos o outro lado da ânfora de Paris, na qual Dionysos recebe a homenagem de duas mênades. A presença das cenas dionisíacas é muito importante na obra do Pintor de Amásis. É o deus que aparece mais frenquentemente nesse corpus $^{49}$ como é o caso, aliás, no conjunto da produção do Cerâmico no final do arcaísmo. No entanto, além da posição muito importante que o Pintor de Amásis lhe atribui, é, sobretudo, a sua forma de representar o universo dionisíaco que se revela original. No vaso do Cabinet des Médailles, a figura do deus, em si, é tradicional. Por sua vez, as duas figuras femininas que avançam em sua direção, dançando e trazendo-lhe os produtos de sua caça, surpreendem mais. A dança animada, claro, é uma das características desse tipo de personagem. Alguns atributos permitem, também, identificá-lo: constituem o que poderíamos chamar de "libré" dionisíaca, o conjunto de objetos que marcam o pertencimento ao deus e caracterizam esse tipo iconográfico. No nosso vaso, elas vestem a coroa e o ramo de hera, a planta sempre verde, familiar à imagem do próprio deus, fortemente ligada à natureza e cujo poder não conhece limite temporal. Uma delas também veste a pardalide, a pele de pantera, amarrada em seu péplos. Voltarei a esse ponto.

Pode-se datar a constituição desse tipo iconográfico de mênade por volta de meados do século VI a. C., um pouco antes, sem dúvida, na obra do Pintor Lydos e de alguns pintores de ânforas tirrenas e, em seguida, do Pintor de Amásis. ${ }^{50}$ Atitudes, gestos e, sobretudo, atributos começam a diferenciá-lo com clareza. ${ }^{51}$ Contudo, Lydos representa a figura, de bom grado, em um contexto narrativo, como no retorno de Hefestos ao Olimpo, escoltado por Dionysos e seu cortejo

\footnotetext{
48Uma sondagem rápida na obra de Exéquias, outra personalidade importante do Cerâmico à época, mostra que Poseidon só aparece nas assembleias divinas: as que recebem Héracles no Olimpo: ânforas de Orvieto, coleção Faina 2748 e 2745: ABV 144,9; 145,11 e 686; BA 310391 e 310393; Mackay (2010, pl.41 e 47); cratera em forma de cálice, Atenas, Ágora AP 1044: ABV 145,19 e 672,4; BA 310401; Mackay (2010, pl.81).

${ }^{49}$ Para um ensaio estatístico, ver Puig (1999, p.169-180; 2009, p.109-122).

${ }^{50}$ Tentei retraçar o início desse tipo iconográfico (2009, p.79-108).

${ }^{51}$ Edwards (1960, p.78-87) traça o perfil da mênade caracterizada por atributos constitutivos do tipo iconográfico, sendo retomado e debatido por Heinrichs (1987, p.100-102).
} 
de mênades e sátiros, ${ }^{52}$ enquanto nosso pintor representa cenas de homenagem ao deus não relacionadas com eventos determinados. Notemos, enfim, que um dos domínios dionisíacos por excelência, o vinho, só foi conotado na cena da ânfora do Cabinet des Médailles por meio do cântaro empunhado pelo deus. As duas mênades não têm qualquer contato com a bebida divina. Buscou-se, não raro, limitar esse modo de acesso ao deus ao mundo masculino, e várias cenas representadas pelo nosso pintor apresentam jovens prestando a homenagem do vinho ao deus. ${ }^{53}$ No entanto, ele também representou mênades com um cântaro ou uma oenochoé na mão, em torno do deus ${ }^{54}$ ou, ainda, enlaçadas por um sátiro. ${ }^{55}$ Nosso pintor também conhece esse aspecto subversivo, um dos componentes da figura feminina no círculo dionisíaco. Eu interpretaria, no contexto específico do tema iconográfico em formação, a variedade de figuras dionisíacas femininas em sua obra. De fato, em volta de Dionysos, seja na mesma cena das mênades vestidas e usando atributos, seja em cenas separadas, ele representa figuras femininas nuas, embora, no imaginário arcaico, somente as hetairai (as prostitutas) sejam representadas dessa forma.

\section{Essa pesquisa rápida dentro do corpus iconográfico do Pintor de Amásis evidencia a importância do deus Poseidon nas suas escolhas e/ou nas de quem as orienta}

Em uma ânfora perdida de Berlim ${ }^{56}$ (figura 5), Dionysos ocupa o centro da composição, cercado de dois casais formados por uma mênade nua, com o braço em volta do ombro de um sátiro itifálico, e de duas mênades vestidas e coroadas de hera. Aquelas que eu qualificaria de mênades nuas ${ }^{57}$ reproduzem o modelo iconográfico das hetairai. O que torna essa imagem possível é um componente da personagem menádica, presente desde a constituição da figura, que a acompanha ao longo de toda a sua história, com fortes reaparições, às vezes, e que faz dela uma mulher fora das normas. ${ }^{58}$ Longe de estar reclusa no espaço do gineceu, dedicando-se às tarefas domésticas e familia-

\footnotetext{
${ }^{52}$ Cratera com colunatas, Nova Iorque, MMA 31. 11.11, aproximadamente 550: ABV 108, 5; Paralipomena 43; BA 310151; Puig (Op. cit., fig. 19-20).

53Por exemplo, na face A da ânfora de Munich 8763 (Paralipomena 65; BA 310434; Bothmer, 1985, p.79-80, n4), Dionysos, em pé, em frente a uma grande ânfora colocada no chão, entrega seu cântaro a um homem jovem, que o enche usando uma oenochoé. Um segundo jovem carrega outra, enquanto dois outros avançam na direção do deus com carnes de caça; no tocante às cenas de sátiros na prensa, ver infra notas 64-65.

${ }^{54}$ Ânfora de Basileia, Kä 42O: Paralipomena 65; BA 350468; CVA 1, pl. 29.

${ }^{55}$ Ânfora fragmentada de Samos, Museu de Vathy K 898: ABV 151,18 e 687; BA 310445; Beazley (1986, fig. 56, 2). ${ }^{56}$ Berlim 321O: ABV 151,21 e 687; BA 310449; Dionysos verwandlung und ekstasie, catálogo de exposição, sob a direção de Renate Schlesier e Agnès Schwazmaier, p.50, n 8, Staatliche Museen zur Berlin e Schnell \& Steiner, Regensburg, 2008, p.50, n 8; ver, também, a ânfora fragmentada de Samos K 898, citada na nota 56; cabe notar um exemplo coríntio anterior, no lécito de Berlim 3243, datado aproximadamente de 560: Dionysos p.18 e p.180-181, n 31: sátiros e mulheres nuas de pele branca são representados em symplegma.

${ }^{57 B e a z l e y ~(1986, ~ p .56) ; ~ B o t h m e r ~(O p . ~ c i t ., ~ p . ~ 49, ~ f i g . ~ 43: ~ " m a e n a d s ") ; ~ c o n t r a r i a m e n t e, ~ I s l e r-K e ́ r e ́ n y i ~(2007, ~ p .134 ~}$ "hetairai"); ver Puig (2012, p.209-223).

${ }^{58}$ Ver, por exemplo, Neils (2000, p.203-226).
} 
res, ela percorre espaços selvagens e caça como um homem. Também como um homem, ela bebe vinho. Sendo assim, a nudez, longe de representar qualquer nudez ritual, expressa, parece-me, esse mesmo aspecto da personagem.

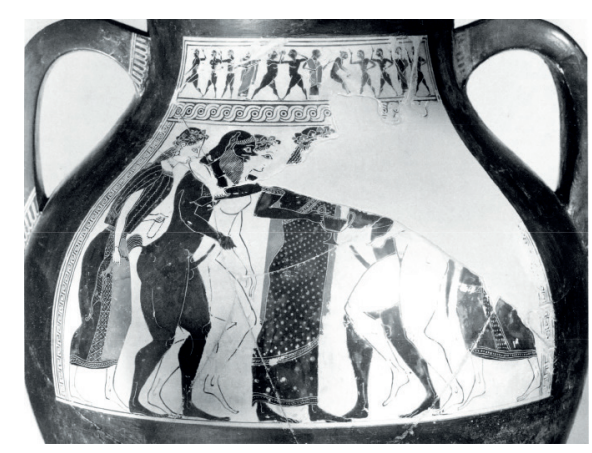

Figura 5: Ânfora perdida de Berlim.

As mênades da nossa ânfora estão, também, caracterizadas como caçadoras, em razão da caça que cada uma delas traz para o deus. Porém, a caça é uma atividade tipicamente masculina, e o tema dos jovens caçadores que homenageiam o deus com o produto de sua caça está asseverado, como vimos, no corpus do pintor. Este representou, também, outra mênade, que entrega uma lebre morta a Dionysos. ${ }^{59}$ Sendo assim, essas figuras expressam um aspecto transgressivo da mênade, que pratica uma atividade masculina: a caça. Lida-se, aqui, com uma representação original da personagem, da qual se encontra outra expressão, literária e bem mais tardia, na tragédia As Bacantes, de Eurípides, criada nos últimos anos do $\mathrm{V}$ século a. C. É por isso que a significação erótica da caça presenteada ao bem-amado, amplamente comprovada e estudada ${ }^{60}$ (encontra-se, no mínimo, um exemplo para o Pintor de Amásis) ${ }^{61}$ parece-me estrangeira a essa representação.

As duas mênades da nossa ânfora estão sozinhas diante do deus, em ausência de qualquer elemento masculino - sátiros que formam, com elas, o thíasos tradicional ou figuras masculinas mais próximas do kômos do que do thíasos. ${ }^{62}$ No universo dionisíaco do pintor, ambos estão presentes. ${ }^{63}$ Ele também

\footnotetext{
${ }^{59}$ Berlim 3210, ver supra nota 57.

60Ver, em particular, Schnapp (1997); no tocante ao sentido da caça no contexto dionisíaco, ver Heinrichs (1987, p.103-105): a mênade que segura um animal é vista como uma descendente da Mestra dos animais. ${ }^{61}$ Taça escifo do Louvre A 479: ABV 156, 80 e 680; BA 310509 e Bothmer (1985, p.200-203, n 54), na qual casais trocam presentes: encontram-se tanto a lebre quanto o cervídeo, mas em um contexto homoerótico masculino; as duas mulheres, igualmente nuas, como todas as figuras da taça, não ganham uma caça, mas são presenteadas com uma galinha e um botão de lótus.

62Para uma definição precisa do tíaso, ver Jaccottet (2003, p.15-29); quanto à passagem do komos para o tíaso no círculo de Dionysos, ver Puig (2009, p.79-84 e 95-97).

63 A respeito de Dionysos cercado de sátiros e mênades, ver, por exemplo, a taça do Louvre F 75 (o deus está acompanhado de Ariadne): ABV 156,81 e 688; BA 310510; Bothmer (Op. cit., p.210-211, n 57); ou os frisos secundários da ânfora de Wurtzbourg L 265: ABV 151,22; BA 310451; Bothmer (1985, p.61, nº 19); mênades e figuras masculinas nuas na ânfora de Basileia, Antikenmuseum Kä 420: Paralipomena 65; BA 350468, CVA 1 , pl.29 ou a ânfora do Louvre F 36: ABV 150,6 et 687; BA 310433; Bothmer (1985, p.81, nº 5).
} 
representa o deus em círculos estritamente masculinos: sátiros vindimadores, por exemplo, na prensa ${ }^{64}$ (podendo ter sido o primeiro a compor tais imagens, nas quais a fabricação mágica do vinho é imediatamente relacionada ao seu consumo e aos efeitos do mesmo), ou, ainda, jovens caçadores, totalmente humanos.$^{65} \mathrm{O}$ universo do vinho e o da caça são territórios masculinos, que entram, ambos, no complexo e rico universo do deus. No entanto, essa mênades "entre elas", diante de seu deus, fornecem uma visão marcada da conivência entre Dionysos e as mulheres, um elemento que estava presente nos primórdios do tema.

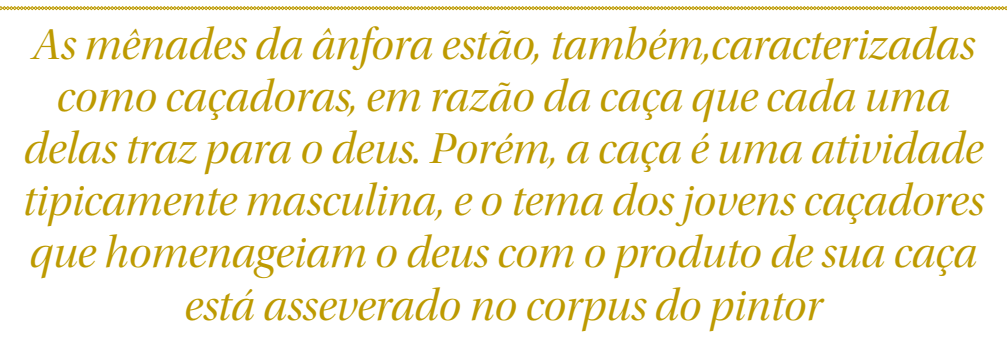

Em uma ânfora "tirrena" do Louvre (figura 6), ${ }^{66}$ datada dos anos 560-550 a. C. - uma das mais antigas cenas menádicas, levemente anterior à ânfora do Cabinet des Médailles -, Dionysos está sentado em frente a uma grande videira, cercado de seis mênades, na ausência de qualquer presença masculina. Apesar da condição frusta, sua dança agitada é perceptível em suas pernadas e nos movimentos de cabeças e braços. Duas delas seguram animais, que figurariam entre os atributos menádicos tradicionais: uma serpente e um jovem felino, sem dúvida, uma pantera. Isso foi observado inúmeras vezes: o contato com Dionysos é mais fácil para as mulheres do que para os homens, que, na maioria das vezes, se tornam sátiros - criaturas mistas, metade homem, metade animal - para se aproximarem do deus. As mulheres, pelo contrário, conservam toda a sua aparência humana, mas, ainda assim, as duas mênades vestem pele de animal, amarrada sobre a roupa. A proximidade com o deus faz delas intermediários privilegiados entre ele e a pólis.

\footnotetext{
${ }^{64}$ Ânforas de Wurtzbourg L 265 e de Basileia Kä 420, citadas na nota 64.

${ }^{65} \mathrm{Na}$ ânfora de Munique 8763: Paralipomena 65; Bothmer (1985, p.79-80, n 4), Dionysos está cercado de quatro jovens caçadores que carregam vinho; na ânfora de Bloomington, Indiana University Art Museum 71. 82: Paralipomena 65; BA 350464; Bothmer (1985, p.63 e p.74-75, n² 2), o deus está cercado de quatro jovens nus, armados com lanças e acompanhados de dois cachorros.

66Louvre E 831: ABV 103,108; Paralipomena 35,108; BA 310451: a ânfora é atribuída por Kluiver (2003, p.80-81 e p.166, $n^{\circ}$ 211) ao Pintor de Guglielmi e datada, por ele, em 560-550, aproximadamente; Puig (2009, p.98-99, fig.18) traz um debate sobre a datação da obra.
} 


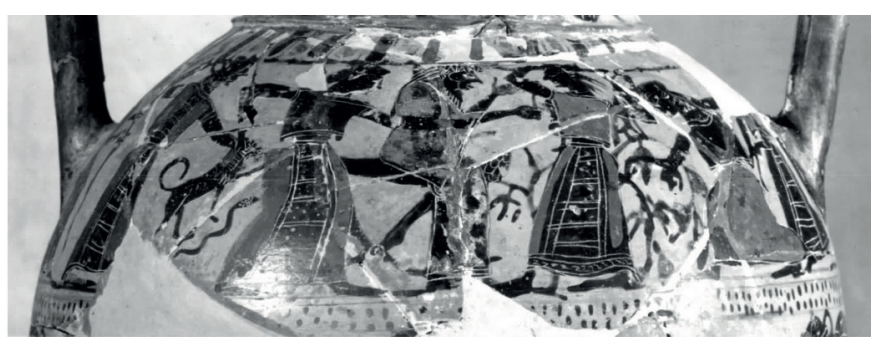

Figura 6: Ânfora "tirrena" do Louvre.

Enfim, a gestualidade das duas figuras, que se aproximam do deus dançando e passando, cada uma, o braço em volta do pescoço da outra, foi abundante e diversamente comentada. Buscou-se, às vezes, dar-lhe um significado homoerótico ${ }^{67}$ No entanto, encontra-se esse mesmo gesto duas vezes no corpus dionisíaco do Pintor de Amásis: dois sátiros são representados dessa forma, enquanto se associam a uma dança em torno do deus, particularmente animados sob o efeito do vinho; ${ }^{68}$ um sátiro e uma mênade também se dirigem, de braços dados, rumo à prensa, na qual dois sátiros, sob o olhar do deus, se apressam em preparar o vinho; outros dois seguram, da mesma forma, duas mênades nuas, coroadas de hera ${ }^{69}$ Sendo assim, o significado homoerótico do gesto parece improvável. Aliás, para defendê-lo, aventa-se a comprovada existência desse tipo de relação erótica entre mênades, que vivenciariam, em seu apego a Dionysos, uma fase de transição entre uma etapa da vida e outra, como vivenciado em Brauron, na esfera de Ártemis, e que se expressa, no caso das meninas atenienses, por "fazer o urso" à deusa. ${ }^{70}$

Essa analogia é pertinente? Pessoalmente, eu destacaria dois pontos. Por um lado, no grande estudo que dedicou à homossexualidade grega, ${ }^{71}$ Dover mencionou o silêncio dos textos e das imagens áticas no que diz respeito à homossexualidade feminina. Além disso, nas Bacantes de Eurípides, o rei Penteu acusa as Bacantes do Citerão, a montanha de Tebas, de prestarem culto a Afrodite, e não a Dionysos, e de se absterem ao relacionamento com homens (v. 221-225: o termo utilizado, arsen, significa, mais exatamente, machos). Certamente, a má conduta das mulheres sob a ascendência de Dionysos é temida pelos homens, mas nenhum texto, nenhuma imagem, que eu saiba, envolve explicitamente uma relação homoerótica entre elas. Sendo assim, nessa marcha alegre das duas mênades que dançam de braços dados na ânfora de Paris, eu veria mais uma expressão coreográfica de uma forma de solidariedade e cumplicidade femininas, presentes no menadismo, essa sim, documentada por uma fonte literária. Trata-se de um texto raro, que nos coloca na presença de uma cena de prática religiosa vivenciada. Plutarco ${ }^{72}$ relata que, em Delfos, o grande santuário de Apolo, onde

\footnotetext{
67Rabinowitz (2002, p.128-129); Isler-Kerényi (1990, p.63 e 2007, p.134-135).

${ }^{68}$ Ânfora de Wurtzbourg, L 265, ver nota 65.

${ }^{69}$ Ânfora de Berlim 3210, ver nota 53.

${ }^{70}$ Analogia proposta por Isler-Kérényi (2007, p.135).

${ }^{71}$ Dover (1989).

72Plutarco, De Mulierum virtute 13, Moralia, 249.
} 
Dionysos ocupa uma posição importante, quando da terceira guerra sagrada, no momento em que os Fócios tomam Anfissa (354/353), algumas thyiades - nome das mênades em Delfos Puig (1986, p.31-51). ${ }^{73}$-, sob influência da mania que Dionysos lhes inspirou, se desgarram à noite, até Anfissa, onde adormecem, exaustas. Mulheres da cidade, temendo por elas devido à presença de muitos soldados na pólis e impulsionadas por uma espécie de solidariedade espontânea, vão até elas, cuidam delas, as alimentam e as encaminham até a fronteira. Plutarco escreve, é certo, muito depois do evento que relata, mas é um excelente conhecedor de Delfos. Esse episódio, por vários motivos interessante, seria, na minha opinião, um testemunho sobre uma forma de solidariedade entre mulheres no menadismo, que o Pintor de Amásis expressa à sua maneira.

Por fim, notou-se, na elaboração dessa figura iconográfica - assim como na da tragédia, bastante visual -, a presença de elementos cultuais, extraídos pelo pintor de celebrações, vistas e conhecidas por ele, assim como pelos seus clientes do Cerâmico. ${ }^{74}$ Sendo assim, o esforço para distinguir, dentre as figuras menádicas, as que pertencem à mitologia e as que pertencem à realidade ou, ainda, a situação de tal cena do corpus, em âmbito humano, e tal outra, no mitológico ${ }^{75}$ parece-me vã. Na própria elaboração, a figura iconográfica mistura elementos para expressar o ser da mulher, em contato com o deus, a mulher que, pelo ritual, se torna mênade. Um exemplo extraído de um lécito de figuras negras anônimo, datado dos anos 510 a. $\mathrm{C}^{76}$ (figura 7), pouco depois do final da carreira do nosso pintor, permite visualizar, com certa clareza - pois o tratamento é menos elaborado -, o trabalho de "bricolage" que foi a "invenção" da figura menádica. Coroado de hera, o deus, empunhando um grande cântaro e um ramo de vinha, assiste às evoluções de três mênades, sozinhas diante do deus, sem qualquer figura masculina, como na nossa ânfora. Coroadas de hera, como o deus, elas vestem, além disso, uma pele mosqueada, amarrada sobre o chiton. Uma delas brande uma lebre, como uma das duas figuras da ânfora do Pintor de Amásis. Outra brande uma serpente, atributo menádico já presente na obra de $\operatorname{Lydos},{ }^{77}$ mas que o nosso pintor parece não ter representado, e um tirso, o caule de junco encimado por um buquê de hera, que acabava de aparecer na obra dos pintores de figuras vermelhas ditos "Pioneiros": Euphronios, Smikros, Phintias, Euthymidès, por volta de 520-515 a. C., para se tornar o emblema menádico por excelência. ${ }^{78} \mathrm{~A}$ atividade delas

\footnotetext{
${ }_{33}^{73}$ uig (1986, p.31-51).

${ }^{74} \mathrm{~A}$ difusão das obras do pintor (Bothmer, 1985, p.46) faz aparecer compradores atenienses, assim como uma importante exportação para a Etrúria e muitas regiões do mundo antigo; não entrarei, aqui, na questão da influência do gosto dos clientes estrangeiros; sobre esse ponto, reuni um dossiê (2015, p.7-198).

${ }^{75}$ Isler-Kérényi (2007, p.132, "human level" e p.134) fala a respeito das figuras femininas da ânfora de Berlim 3210: justaposição de dois tipos femininos, "the hetaerae, erotic companions of the satyrs and the nymphs belonging to the world of nature, not connected with male figures". No entanto, um dos raros textos literários arcaicos conservados sobre os silenos não faz deles "aqueles se unem amorosamente (às ninfas) no fundo de grotas encantadoras" (Hymne homérique à Aphrodite, v.262-263).

${ }^{76}$ Viena, Kunsthistorisches Museum 364 (IV, 196): C.H. Emilie Haspels, Attic black figured lekythoi. Paris, 1936, 53; BA 41017; Puig (2009, p.195-196 e figs. 43,44,45).

77Cratera Nova lorque MMA 31 11 11: ABV 108,5 et 684; BA 310151; Puig (2009, p.104-105 e figs. 19,20).

${ }^{78}$ Por exemplo, na cratera em forma de cálice do Louvre G 33, atribuída a Euphronios: ARV 14; Pasquier e Denoyelle (1990, n¹1).
} 
gira em torno da preparação do vinho a ser bebido, relacionado ao cântaro empunhado pelo deus. Uma delas enche uma hydria, com o vaso de água na fonte - da qual vemos a boca, em forma de boca de leão -, enquanto a outra esvazia o conteúdo da sua na cratera, na qual é operada a mistura correta de água e vinho, para seu consumo. A cena transcorre sobre um fundo de ramos de videira, que reforçam o seu caráter dionisíaco.

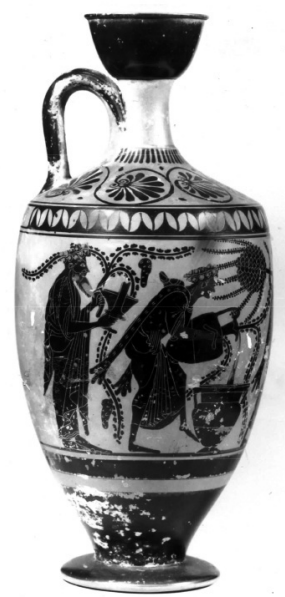

Figura 7A: Lécito ático de figuras negras.

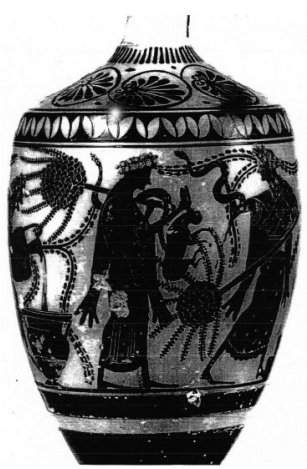

Figura 7B: Lécito ático de figuras negras.

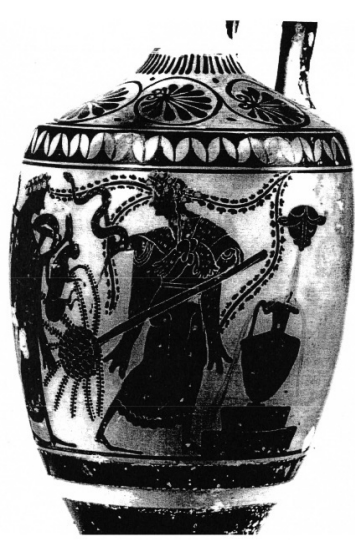

Figura 7C: Lécito ático de figuras negras. 
Minha última observação será sobre a técnica do Pintor de Amásis. De fato, a pele das duas mênades da ânfora de Paris não recebe um tratamento com realces brancos, como é costume nas figuras negras, e sim, com traços de contorno que fazem aparecer, para significar a pele, a cor alaranjada da argila. Essa particularidade é encontrada, na obra do pintor, em cinco outros vasos integralmente conservados ou fragmentados. ${ }^{79}$ Viu-se nisso uma inovação, que o aproxima dos vasos de figuras vermelhas, surgida no Cerâmico por volta de 530 a. C., durante o último período de sua carreira. Ele se situaria, assim, no limiar da novidade.

Em um estudo dedicado à técnica do pintor e à sua maneira artística, ${ }^{80} \mathrm{~J}$. Mertens também sugere que essas tentativas, estranhas à tradição da figura negra mais "ortodoxa", se referem, com uma única exceção, às figuras de mênade. Essa única exceção é uma figura feminina em uma representação de partida de um guerreiro: ${ }^{81}$ a cena não está inscrita, mas a sumptuosidade do escudo propenderia para uma cena heroica, como a de Aquiles diante de sua mãe, Tétis. Essa figura feminina é, de certa forma, "uma anônima carregadora de escudo", uma espécie de modelo heróico. O pintor teria sentido sua imaginação mais livre e testado, principalmente, o tratamento de tais figuras, fora do tempo, de estado flutuante. $\mathrm{O}$ autor observa, além disso, que, na ânfora de Berlim, ${ }^{82}$ as duas mênades nuas, inteiramente representadas com traços de contorno, contrastam fortemente com o corpo negro de seu companheiro. Esse efeito visual marcado corresponderia a uma forma eficaz de acentuar um aspecto específico da personagem menádica, totalmente "liberada".

As figuras femininas representadas na nossa ânfora apresentam, portanto, vários traços originais. Em primeiro lugar, expressa-se a cumplicidade entre o universo feminino e o deus. Além disso, uma vez que as mênades do Pintor de Amásis estão localizadas, temporalmente, perto da elaboração desse tema iconográfico, o pintor testa uma grande variedade de fórmulas, relacionadas aos aspectos constitutivos mais essenciais da personagem. As mênades da ânfora de Paris constituem, por essa ótica, uma imagem impressionante de uma forma de felicidade dionisíaca exaltada e cúmplice entre duas figuras femininas que se aproximam, em uma viva dança, da divindade, a fim de oferecer-lhe a presa resultante de sua caça. Isso evoca suas andanças na natureza selvagem, longe daquilo que é considerado como o universo feminino tradicional.

Há originalidade em certos elementos da decoração secundária e na maneira - sem qualquer parelelo conhecido - de representar cenas figuradas, cujo tema lhe é efetivamente contemporâneo. O que sabemos desse pintor anônimo que possa dar conta desses traços que parecem pessoais? Certamente, sabemos muito pouco sobre os artesãos do Cerâmico, que testemunha, nesse final do arcaísmo, uma forte efervescência criativa. Contudo, no caso do nosso pintor

${ }^{79}$ Ânforas Berlin 3210 (perdida) e Basileia col. Käppeli 420, ver notas 56 e 55; fragmentos de ânfora de Nova lorque 1985.57: Bothmer (1985, p.110-112 n 18bis); de Samos e de Kavalla (ibidem p.109, fig. 67 e p.116, fig. 76). 80Mertens (1987, p.171-176).

${ }^{81}$ Berlim 3210 ver supra nota 56 reverso.

${ }^{82}$ Berlim 3210, ver nota 57. 
anônimo, um nome está, no entanto, vinculado aos vasos que ele decorou, o do oleiro que os assinou: Amásis. Ora, esse nome estrangeiro fornece uma pista que não deve ser negligenciada.

Nossa ânfora foi atribuída por Beazley ${ }^{83}$ ao Pintor de Amásis, um pintor anônimo que recebe seu nome do oleiro Amásis, de quem vimos a assinatura na ânfora e de quem se conhecem várias outras assinaturas. ${ }^{84}$ Critérios estilísticos permitem observar a frequentíssima colaboração entre os dois artesãos, embora não se possa assimilar um ao outro com absoluta certeza. Ele é o primeiro pintor de vasos a quem se dedicou uma exposição monográfica, em Nova Iorque, em $1985 .{ }^{85}$ Ela reuniu cerca de sessenta vasos, dentre os cento e trinta que lhe eram atribuídos até então, distribuídos ao longo de sua extensa carreira, que é situada entre 560 e 515 a. C. No catálogo da exposição, Bothmer indica que, embora todos os vasos assinados pelo oleiro Amásis sejam atribuídos ao mesmo pintor, o Pintor de Amásis - e que haja, portanto, uma tendência em confundir o pintor com o oleiro -, um lécito, adquirido pelo Museu Getty, traz a assinatura do oleiro Amásis, mas é atribuído ao Pintor de Taleidès. ${ }^{86}$ Além disso, a cronologia que ele propõe da carreira do pintor, com início por volta de 560 a. C., torna difícil ele ter podido receber o nome de Amásis em referência ao do faraó, cujo reinado tinha começado havia muito pouco tempo. ${ }^{87}$ Ademais, nenhum dos vasos assinados por Amásis pertence à primeira parte da carreira do pintor, portanto, a exposição teve como objeto o anônimo Pintor de Amásis. A questão de ser uma única pessoa continua atravessando a pesquisa e não acolheu, até hoje, qualquer conclusão.

Notemos, no entanto, o uso feito por Beazley dos termos Amasian e Amasea para caracterizar uma maneira de pintor e de oleiro, ${ }^{88}$ assim como sua observação sobre o Pintor de Amásis: "A great part of the pleasure one receives from the vases he decorated, whether signed or unsigned, is due to the potter-work, the shape and surface-finish, in fact to Amasis, and the potter Amasis is as clearly defined a personality as the Amasis Painter; he has his own idea of shape, and goes his own way, keeping apart from the majority." ${ }^{89}$

Detenhamo-nos, por um momento, no nome Amásis: uma forma helenizada de um nome egípcio comprovado e, em particular, de um faraó, que reinou de 570 a 526 a. C. e se mostrou filelênico em um período já avançado de seu reino. $\mathrm{O}$ historiador Heródoto relata vários testemunhos disso. ${ }^{90} \mathrm{O}$ nome do oleiro foi, naturalmente, relacionado ao do soberano de várias formas e induziu muitos questionamentos sobre as suas origens. Pode-se tratar de um ateniense com nome de soberano estrangeiro. ${ }^{91}$ Não seria o único exemplo de

\footnotetext{
${ }^{83} \mathrm{ABV}, 152,25$

${ }^{84}$ Beazley (ABV, p.152 -158) menciona 8 assinaturas em vasos de figuras negras e uma em um vaso de figuras vermelhas (retomado ARV 160: Ama Group); Bothmer (1985, p.35) menciona 12 ou 13 assinaturas.

${ }^{85}$ Sobre o catálogo de exposição, ver supra nota 2; para os anais de colóquio que o acompanhou, nota 44.

${ }^{86}$ Bothmer (1985, p.34 e p.229)

${ }^{87}$ Esse problema já foi objeto de uma explanação clara, em uma nota de Cook (1948, p.148).

${ }^{88}$ Beazley (1931, p.256-285) reúne tanto obras do oleiro como do pintor.

${ }^{89}$ Beazley (1986, p.52).

90Heródoto, II (p.178-182)

${ }^{91}$ Karouzou (1956).
} 
um cidadão de Atenas nomeado desse modo. De fato, o efebo Croisos, que deve seu nome ao rei Creso da Lídia, nos é conhecido por sua bela estátua funerária, realizada por volta de 530 a. C. ${ }^{92}$ Mas, no caso de Amásis, surge um problema cronológico de difícil resolução: o jovem ateniense só poderia receber esse nome quando do seu nascimento, em relação ao do faraó - preferencialmente, no período em que este demonstrou sentimentos filelênicos, e não no início do seu reino. No entanto, a datação tradicional atribuída à obra do pintor dificilmente se encaixa nessa exigência. Foi proposto, também, um nascimento no exterior para o futuro artesão do Cerâmico de Atenas: ele pode ter nascido no Egito e recebido, neste caso, um nome egípcio comprovado, sem que este esteja necessariamente ligado ao do faraó, mas, enquanto criança grega, seu nome aparece na transcrição grega. ${ }^{93}$ Sugeriram especificamente Naucratis, o importante porto comercial do delta do Nilo, onde residia uma enorme colônia grega, como local de nascimento. Lá, ele poderia ter visto os produtos dos ateliês da Grécia continental e da Jônia. Poderia, até mesmo, ter conhecido os ateliês locais de gregos da Jônia, lá instalados, e adquirido, dessa maneira, graças ao contato com uma produção variada e de alto nível técnico e artístico, uma formação que o acompanharia em Atenas, quando ele lá se instalou como meteco. ${ }^{94}$

J. Boardman propôs, em um importante estudo dedicado ao seu nome, ${ }^{95}$ vermos nele um grego da Jônia, um ambiente em contato com o Egito - de modo que o nome do oleiro não seria insólito - e onde a produção de vasos pintados apresenta características próprias e claramente marcadas na forma e na decoração, das quais se pode buscar vestígios na obra do oleiro ou do pintor-oleiro Amásis. É preciso lembrar que Exéquias, seu vizinho no Cerâmico (seu rival?), talvez tenha aludido ao seu rosto exótico em uma ânfora, na qual, ao lado do acompanhante negro do rei Mêmnon, se pode ler o nome Amásis. ${ }^{96}$

Depois da exposição e do colóquio de 1985-1987, centrados no pintor, as pesquisas têm se voltado mais para o oleiro, respondendo, assim, à vontade expressa, à época, por Boardman. ${ }^{97} \mathrm{H}$. P. Isler foca sua pesquisa no argumento cronológico e na imperativa vinculação do nome de Amásis ao do faraó, cujo reinado está corretamente datado. Isso o leva a rever a datação da carreira do pintor e a iniciá-la um pouco mais tarde, por volta de 550-545 a. C. ${ }^{98}$ Assim, pintor e oleiro podem ser uma pessoa só ou, pelo contrário, dois artesãos diferentes; a questão segue aberta.

Por sua vez, H. Mommsen foca o seu estudo no oleiro. ${ }^{99}$ Após ter questionado a autenticidade da assinatura de Amásis no lécito da Villa Getty, ${ }^{100}$ ela se

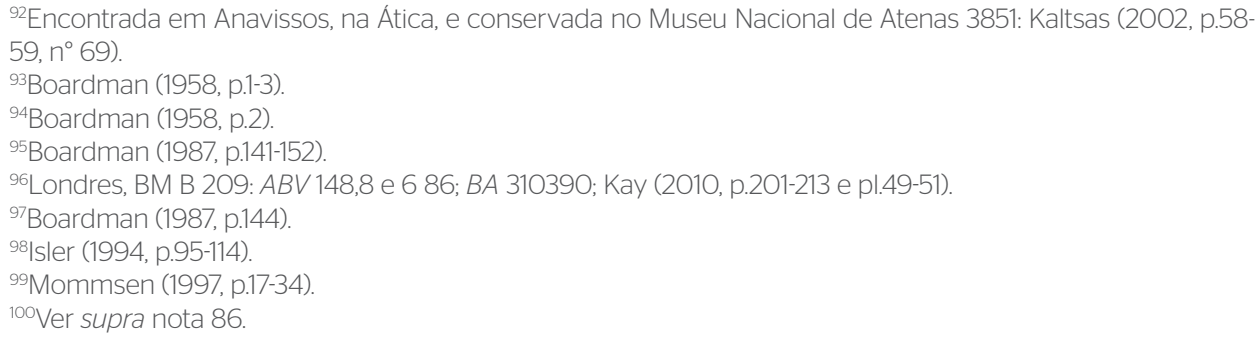


dedica, em particular, a identificar os traços que caracterizam a sua maneira. Um ponto concerne particularmente o nosso assunto: sua fina análise da ânfora do Cabinet des Médailles extrai a profunda originalidade de sua forma, comparável à Botkin Class devido a alguns detalhes, mas que constitui uma obra original do oleiro Amásis. Sua análise do trabalho do oleiro a conduz, desse modo, a definir a maneira original como ele assimila influências para criar obras profundamente pessoais. Dispomos, aqui, de dados preciosos sobre a maneira própria de Amásis, o oleiro. Além disso, para a autora, a unidade entre esse trabalho e o do pintor é tamanha que ela não pode deixar de pensar em um único artesão, ao mesmo tempo oleiro e pintor. ${ }^{101}$ Sua mais recente contribuição ${ }^{102}$ continua insistindo na profunda coesão da forma e da decoração e na possível confusão entre o oleiro e o pintor.

Em outras palavras, essa pesquisa nos convida a continuar nessa mesma direção, agora, a respeito do pintor, em suas escolhas iconográficas. Sua possível origem exótica influencia os temas que ele representa nos vasos e a maneira como os elabora? Seu estilo foi analisado, quase de modo unânie, como tipicamente ático. Não se percebe qualquer ar estrangeiro nas formas ou no estilo, segundo Bothmer, que fixou a lista daqueles que o influenciaram na esfera do Cerâmico de Atenas, sendo o principal deles o seu antecessor, o Pintor de Heidelberg. ${ }^{103}$ No entanto, J. Boardman, justamente em sua contribuição dedicada às implicações do seu nome, atenta judiciosamente para a quantidade de pintores de vasos ou, ainda, de escultores, nascidos ou formados em outros lugares, que contribuíram para a formação do estilo ático. $\mathrm{O}$ da pintura de vasos, desenvolvido em Atenas, é fruto de uma mistura de influências variadas, de origens diversas. ${ }^{104}$ Ele prossegue, questionando-se, ponto essencial para a presente pesquisa, sobre a escolha de seus temas, a maneira como os aborda e sua originalidade nesses quesitos em relação aos seus contemporâneos, como Exéquias, e, também, à tradição ática majoritária, que vai de Clítias a Exéquias, passando por Lydos. ${ }^{105}$

À guisa de conclusão, gostaria de destacar o grande interesse do programa iconográfico da ânfora do Cabinet des Médailles, notável em muitos sentidos. De fato, as três divindades nela representadas corroboram o que outras fontes nos ensinam a respeito do universo sócio-religioso de Atenas no tempo dos Pisistrátidas. Outros pintores do Cerâmico, Exéquias, por exemplo, confirmam a importância dessas divindades. Ainda assim, se observarmos com acuidade, a maneira como o Pintor de Amásis as representa lhe é exclusiva. O momento escolhido, sem contexto narrativo, e a atitude estática das três divindades representadas nas duas faces do vaso acentuam sua potência divina. Além disso, a imagem da confrontação entre Athená e Poseidon, em uma época em que,

\footnotetext{
101Mommsen (1997, p.17-34).

102Mommsen (2009, p.40).

${ }^{103}$ Bothmer (1985, p.38-42)

104Boardman (1987, p.146, com menção à contribuição de Alan L. Boegehold na introdução do catálogo da exposição, p.31; Viviers (1992) fornece uma imagem cativante.

${ }^{105}$ Boardman (1987, p.147).
} 
como comprovam alguns documentos, o tema de sua rivalidade pela posse da Ática já era, muito provavelmente, conhecido, revela-se original, na medida em que as duas divindades são apresentadas em pé de igualdade, como se, uma vez decidido o conflito em favor de Athená, cada uma tivesse encontrado o seu espaço na Acrópole. Ademais, nosso pintor dá, no conjunto de sua obra conservada, uma importância especial ao deus dos mares e "movedor da terra", o que o diferencia entre os artesãos do Cerâmico da época.

Por fim, as mênades que ele representa em frente de Dionysos são excepcionais. Trata-se de um tema iconográfico ainda em formação, para o qual o pintor inventa soluções, ao mesmo tempo únicas e expressivas, no que tange às profundas virtualidades dessa figura, destinada a um surpreendente e durabilíssimo sucesso.

É tentador atribuir esses traços originais a uma possível origem estrangeira do artesão, embora toquemos aqui na questão, ainda sem resposta clara atualmente, da eventual identidade do oleiro que assinava Amásis, um nome com muitas chances de indicar uma origem oriental, e do pintor que decorou a maioria de seus vasos assinados. A profonda originalidade tanto do oleiro quanto do pintor, ambos à margem em comparação com os outros criadores de seu tempo, em vários aspectos, dá a essa assimilação algum poder de sedução. Lembremos que, na época em que acaba a carreira do nosso pintor, é outro estrangeiro em Atenas, o anônimo Pintor de Andócides, que "inventa" a técnica das figuras vermelhas. No cruzamento de influências externas que representa, então, o Cerâmico, atribuir uma forma de originalidade a um pintor-oleiro de origem estrangeira constitui uma hipótese que não deve ser excluída. Em outras palavras, seria uma forma de entrar na difícil problemática da margem de liberdade do artesão na escolha dos temas que aborda e da maneira como os representa.

\section{Abreviações}

ABV: John Davidson Beazley, Attic Black-Figure Vase-Painters, Oxford, Oxford University Press, 1956.

ARV: Beazley, John Davidson. Attic Red-Figure Vase-Painters. Oxford, Clarendon Press, $2^{\mathrm{a}}$ ed., 1963. Paralipomena: Beazley, John Davidson. Paralipomena. Oxford, Clarendon Press, $2^{\mathrm{a}}$ ed., 1971. BA: Beazley Archive, Universidade de Oxford. Disponível em: www.beazlley.ox.ac.uk.

\section{Lista das figuras}

Figura 1AB: Ânfora ática de figuras negras Cabinet des Médailles 222, faces A e B: fotografias de Serge Oboukoff, BnF - CNRS Maison de l'ethnologie et de l'archéologie René Ginouvès, com a gentil autorização do Gabinete das Medalhas, BnF.

Figura 2AB: Ânfora ática de figuras negras do Cabinet des Médailles 222, ombro: por Susanne Muth, Gewald im Bild, Berlim. Nova Iorque, Walter de Gruyter, 2008, p.160-161, figura 86AB. Figura 3: Prato de Tasos, de figuras negras, do templo de Ártemis 2028 $\pi$, atribuído ao Pintor de Atena e de Poseidon: por Anne Coulié, La céramique thasienne à figures noires, Etudes thasiennes 19, 2002, Atenas, EFA, pl. II, $\mathrm{n}^{\circ} 140$.

Figura 4AB: Ânfora pseudo-panatenaica, Museu Nacional de Atenas, Acr 923, atribuído ao Pintor de Princeton, face B: por Patricia A. Marx, "Athens NM Acropolis 923 and the Contest between Athena and Poseidon for the Land of Attica", Antike Kunst. 54, 2011, pl.3 figuras 2 e 3. 
Figura 5: Ânfora ática de figuras negras. Berlim 3210 (perdida), por Dionysos Verwandlung und Ekstasi, catálogo de exposição, sob a direção de Renate Schlesier e Agnès Schwazmaier, p.50, n 8, Staatliche Museen zur Berlin e Schnell \& Steiner, Regensburg, 2008, p.50, figura 8.

Figura 6: Ânfora "tirrena", Louvre E 831: por Marie-Christine Villanueva Puig, Ménades. Recherches sur la genèse iconographique du thiase féminin de Dionysos des origines à la fin de la période archaïque, Paris, Les Belles Lettres, Études anciennes, 2009, figura 18.

Figura 7ABC: Lécito ático de figuras negras. Viena, Kunsthistorisches Museum 364 (IV 196): por Marie-Christine Villanueva Puig, Ménades. Recherches sur la genèse iconographique du thiase féminin de Dionysos des origines à la fin de la période archä̈que, Paris, Les Belles Lettres, Études anciennes, 2009, figuras 43-44-45.

\section{Referências bibliográficas}

BAKIR, Güven. Sophilos. Mayence: Von Zabern,1981.

BAURAIN-REBILLARD, Laurence. Sophilos, un grand artiste du parlant. In: VILLANUEVA PUIG, Marie-Christine et al.: Céramique et peinture grecques. Modes d'emploi. Paris: École du Louvre, Documentation française, 1999.

BEAZLEY, John Davidson. The Development of Attic Black-figure. University of California Press, 1986.

BEAZLEY, John Davison. Journal of hellenic studies. 51, 1931.

BOARDMAN, John. Amasis: the implications of his name, Papers on the Amasis painter and his world. Anais de colóquio, J. Paul Getty Museum. Malibu, 1987.

BOARDMAN, John. The Amasis Painter, Journal of Hellenic Studies. 78, 1958.

BONANSEA, Nicoletta. Menade, baccante o ninfa? Uno studio sull'identità feminile dionisiaca nelle fonti letterarie e iconografiche tra VIII e V secolo a.C., Mythos, 2, 2008.

BOTHMER, Dietrich von. The Amasis painter and his world. Catálogo de exposição, Nova Iorque, Metropolitan Museum of Art, 1985.

COLONNA, Cécile. Du rouge et du Noir. Les vases grecs de la collection de Luynes. Gourcuffgraden, 2013. COOK, R.M. Amasea. Journal of Hellenic Studies, 51, 1931.

COULIÉ, Anne. La céramique thasienne à figures noires, Etudes thasiennes, 19, 2002.

DARTHOU, Sonia. Eris dans la Cité, Quelques réflexions sur les cosmogonies politiques, Mètis, 6, 2008. DENOYELLE, Martine. Chefs-d'œuvre de la céramique grecque. Paris: RMN, 1994.

DOVER, Kenneth James. Greek homosexuality. Cambridge, 1989.

EDWARDS, Mark W. Representations of Maenads on Archaic Red figure Vases, Journal of Hellenic Studies, 80, 1960.

ESPOSITO, Anna Maria e TOMMASO, Giandomenico de. Museo archeologico Nazionale di Firenze. Antiquarium Vasi attici. Florence: ed. Il Ponte, 1993.

HASPELS, Emilie. Attic black figured lekythoi. Paris, 1936.

HEINRICHS, Albert. Myth vizualized: Dionysos and his circle in the sixth-century attic vase-painting. Papers on the Amasis painter and his world. Anais de colóquio, J. Paul Getty Museum, Malibu, 1987. ISLER, Hans Peter. Der töpfer Amasis und der Amasis-Maler. Bemerkungen zur chronologie und zur person, Jahrbuch des deutschen archäologischen Instituts, 109, 1994.

ISLER-KERÉNYI, Cornelia. Identittà maschilli e femminili intorno a Dionysos nell'opera del Pittore di Amasis. Iconografia dionisiaca III, Numismatica e Antichità classiche, 9, 1990.

ISLER-KERÉNYI, Cornelia. Dionysos in Archaic Greece. Leyde-Boston: Brill, 2007.

ISLER-KERÉNYI, Cornelia. Dionysos in classical Athens. An understanding through images Leyde. Brill, 2015.

JACCOTTET, Anne-Françoise. Choisir Dionysos. Zurique: Kilchberg, 2003.

JACKSON, D.A. East Greek influence on attic vases. London: Society for the promotion of hellenic studies, 1976.

JOUAN, François e VAN LOY, Herman (eds.). Euripide VIII, 2, Fragments. Paris: Les Belles Lettres, 2000. KALTSAS, Nikolaos. Sculptures in the national archaeological museum Athens. Atenas: Kapon Editions, 2002.

KAROUZOU, Semni. The Amasis Painter. Oxford: Clarendon Press, 1956.

KLUIVER, Jeroen. The "Tyrrhenian" Group of Black-Figure Vases. Amsterdam, 2003. 
LINDBLOM, Anna. Take a walk on the wild side. The behaviour, attitude and identity of women approched by satyrs on attic red-figure vases from 530 to 400 BC. Stockholm University, 2011. LORAUX, Nicole. "Cité grecque”. Dictionnaire des mythologies, sob a direção de BONNEFOI, Yves, I, Paris: Flammarion, 1981.

MACKAY, E. Anne. Tradition and originality: a study of Exekias. BAR International Series, 2092, 2010. MERTENS, Joan R. The Amasis Painter: Artist and Tradition, Papers on the Amasis Painter and his World, Anais de colóquio. Malibu: J. Paul Getty Museum, 1987.

MOMMSEN, Heide. Die botkin klasse. In: TSINGARIDA, Athena (Ed.). Shapes and uses of greek vases (7th-4th centuries B.C.). Bruxelas: CReA Patrimoine, 2009, p.31-46.

MOMMSEN, Heide., AMA $\mathrm{I} \Sigma$ MEПOIE $\Sigma$ EN: Beobachtungen zum Topfer Amasis In: OAKLEY, J.H., COULSON W.D.E., PALAGIA, O. (Eds.), Athenian Potters and Painters. Oxford, 1997, p. 17-34. MOORE, Mary B. The Princeton Painter, Athena and Poseidon, Antike Kunst, 56, 2013.

NEILS, Jennifer. Others within the other: an intimate look at hetairai and maenads. In: COHEN, Beth (ed.). Not the classical ideal. Leyde: Brill, 2000.

PALA, Elisabetta. Acropoli di Atene. Un microcosmo della produzione e distribuzione della ceramica attica. Roma: L'Erma, 2012.

PARKER, Robert. Athenian religion. A history. Oxford, 1996.

PARKER, Robert. Myths of early Athens. In: BREMMER, Jan (ed.). Interpretations of greek mythology, Oxford: Routledge, 1987.

PASQUIER, Alain e DENOYELLE, Martine (eds.) Euphronios, peintre à Athènes au VIe siècle avant J.-C. Paris: Museu do Louvre, RMN, 1990.

PIRENNE-DELFORGE, Vinciane. Un oikéma appelé Erechtheion (Pausanias, I, 26,5). Paysage et religion en Grèce antique. Mélanges offerts à Madeleine Jost. Paris: De Boccard, 2010.

POTTIER, Edmond. Oenochoe du Musée du Louvre signée par le Peintre Amasis, Revue archéologique, 13, 1889.

RABINOWITZ, Nancy. Excavating women's homoerotism in ancient Greece: the evidence from attic vase painting. In: RABINOWITZ, N.S. e AUANGER, L. (eds.). Among women - from the homosocial to the homoerotism in the ancient world. Austin, 2002.

SCHLESIER, Renate e SCHWAZMAIER, Agnès (dir.). Dionysos verwandlung und ekstasie. Catálogo de exposição. Staatliche Museen zur Berlin e Schnell \& Steiner: Regensburg, 2008.

SCHNAPP, Alain. Le chasseur et la Cité. Chasse et érotique dans la Grèce ancienne. Paris: Albin Michel, 1997.

SHAPIRO, Harvey Alan. Art and cult under the tyrants in Athens. Mayence: ed. von Zabern,1989 (supl. em 1995).

SIMONETTA, Angiolillo. Arte e cultura nell'Atene di Pisistrato e dei Pisistratidi. Bari: ed. Puglia, 1997. SOURVINOU-INWOOD, Christiane. A Reading of two Fragments of Sophilos, Journal of Hellenic Studies, 128, 2008.

STÄHLI, Adrian. Die Vverweigerung der Lüste. Erotische gruppen in der antiken plastik. Berlim: Reimer, 1999.

VILLANUEVA PUIG, Marie-Christine. Se dévêtir pour Dionysos? A propos de quelques représentations de ménades nues sur les vases attiques. In: GHERCHANOC, Florence e HUET, Valérie. Vêtements antiques. S'habiller, se déshabiller dans les mondes anciens. Errance, Arles: Errance, 2012. VILLANUEVA PUIG, Marie-Christine. A propos des thyiades de Delphes, L'association dionysiaque dans les sociétés anciennes. Actes de la table ronde international Ecole française de Rome, 24-25 Mai 1984. Roma: EFA, 1986.

VILLANUEVA PUIG, Marie-Christine. Deux iconographies dionysiaques parallèles: celle du Pintor d'Amasis et celle d'Exékias. Deux personnalités artistiques? In: VILLANUEVA PUIG, Marie-Christine. et al.: Céramique et peinture grecques. Modes d'emploi, Paris, École du Louvre, Documentation française, 1999.

VILLANUEVA PUIG, Marie-Christine. Ménades. Recherches sur la genèse iconographique du thiase féminin de Dionysos des origines à la fin de la période archä̈que. Paris: Les Belles Lettres, Études anciennes, 2009.

VIVIERS, Didier. Recherches sur les ateliers de sculpteurs et la cité d'Athènes à l'époque archaïque: Endoios, Philergos, Aristoklès. Bruxelas: Académie Royale de Belgique, 1992. 